\title{
Carboplatin-Paclitaxel-Etoposide Regimen
}

National Cancer Institute

\section{Source}

National Cancer Institute. Carboplatin-Paclitaxel-Etoposide Regimen. NCI Thesaurus.

Code C63763.

A regimen consisting of carboplatin, paclitaxel and etoposide used for the treatment of extensive-stage small cell lung cancer. 